ББК 81.432.1-51

\title{
LINGUISTIC FEATURES OF NATO'S MEDIA IMAGE (THE CASE STUDY OF BRITISH ONLINE PUBLICATIONS)
}

\author{
Valuyskaya Olga Ruslanovna \\ Candidate of Philological Sciences, Associate Professor, \\ Department of English Philology, \\ Volgograd State University \\ ovalvolsu@mail.ru,english_philology@volsu.ru \\ Prosp. Universitetsky, 100, 400062 Volgograd, Russian Federation
}

\begin{abstract}
The paper investigates linguistic specific means of NATO's image making in online British leading newspapers. The case study involves news reports and analytical articles that represent explicit and implicit evaluation of the North Atlantic Treaty Organization. The investigation is based on the principles of the media linguistic approach and suggests the structural peculiarities of a media image that can be analyzed as a three-sided unit including positive, negative and neutral structural elements of image introduction into a media text. The NATO's image can be viewed as that of a geopolitical actor, creating its Natoland. Certain media topics are analyzed as creating positive and negative images of the NATO as a military organization. A finite list of positive and negative constituents to the Alliance's image is presented in the paper. It is assumed that the simplistic writer-reader model of interaction shapes certain elements of a media image that can be interpreted by a reader. The author distinguishes in the paper the principle constituents of an international organization in general, and the NATO in particular. Findings of the study demonstrate that the NATO's media image is interpreted by the readers as the conceptual entity of two key images: a peacemaker and a hawk that are restored on lexical and intertextual levels
\end{abstract}

Key words: media image, media space, media text, mass media, evaluation, negative opinion, lexical level, intertextual level.

A large number of current humanities research papers in general and linguistic ones in particular are devoted to the investigation of specific features of media text, characteristics of media space, as well as linguistic means of image making as far as political leaders, eminent personalities and $\Xi$ pop stars are concerned. Media texts are analysed $\vec{\sim}$ within media studies and based on three traditions: $\therefore$ the interpretive, social science and creative. Moreover, three approaches to the language of news media are scrutinized $[12$, p. 25]. Some scholars concentrate on the historical and genre analyzing approaches to media texts [6]; others (2) assume that media texts can be studied within intertextual networks of genre and convention [11, p. 59]. A number of authors focuses on the depth of persuasive language techniques, persuasive images and take the following factors into account: audience, purpose, form and language [3, p. 1-4]. Marie Gillespie and Jason Toynbee state that the term "media text" to emphasise the fact that media artefacts construct and express meanings [8, p. 2] and specify that media texts need a reader to activate the meanings of texts that are open to interpretation. A similar idea is put forward by Mike Edwards who considers media texts to be polysemic and open to a number of potential readings $[5$, p. 6]. A communicative approach to the 
investigation of media texts is closely connected with media discourse and intertextuality, internationalization of communication across the world [10, p. 1]. In addition, the concept of a media text is interlinked with the concept of media audience comprising illocutionary and perlocutionary audience [7, p. 307]. The issues of a media text investigation are closely connected with the term "media image"; the latter being mostly depicted in social science studies and media studies. A media image is an essential subject matter of many papers, for example, Africa's media image is examined in a collection by Beverly G. Hawk with a focus issue on metaphors of African coverage by American television, newspapers and magazines [1, p. 3-14]. The Middle East image in American media is represented as a stereotyped and the following key images are given: Middle East region in decline; fundamentalist movement growing; democracy lacking; Arab unity as a facade; Arabs live in the past; slavery exists in parts of the Arab world; and political climate changing (coverage in Time and Newsweek) [16, p. 156159]. Another interesting investigation is the media image of homeless culture; it examines verbal ways in which the homeless are portrayed by the media $[15$, p. 1-3]. A media image of an international organization is also a matter of interest from a linguistic approach $[2 ; 4 ; 9 ; 13]$; a media image is a product of interpretation as "there are no such things as facts without interpretation" $[1$, p. 3].

The article is aimed at analyzing the media image of the North Atlantic Treaty Organization as a military alliance portrayed in the British online mass text, interpreted by the readers, who interpret text and restore its meaning according to the interpretation strategy $[17$, p. 211]. The organization is viewed as the major geopolitical actor that can be defined as one of the key media images in media linguistics [18, p. 5].

The media image of NATO is supposed to be represented in two-dimensional aspects: from the standpoint of dominated media topics determining the specificity of a media image and from the viewpoint of linguistic means of representing the aforementioned specificity. It should be mentioned that the unit of the analysis includes not only a separate lexeme but also a word combination, a syntactic unit and even a textual one (i.e. a text segment which denotes a cohesive finalized sentiment). All these allow to reconstruct NATO's media image and outline the evaluation component in regard to NATO as an interplanetary military and political actor as the one being interpreted by British mass media.

The publications under consideration are news items and analytical articles of leading national British papers which are available on official web sites and contain the information about NATO.

The general analysis of considered material shows an obvious negative attitude towards NATO and its activities as represented in British mass media. The negative evaluation (explicit or implicit) is given to NATO's missions, decisions, self-image, and officials in $41 \%$ of researched media citations. Very few utterances (to be more exact $7 \%$ ) can be regarded as more or less neutral, i.e. such expressions do not contain evaluation components. As for positive media evaluation, it often occurs in British Internet articles. According to our results $52 \%$ of utterances can be viewed as positive. Thus, NATO's media image and its verbal representation in British mass media may be organized as a formal structural linguistic adumbration, which is combined of definite lexical components. The basic lexical core units are the following lexemes and word combinations which may be called secondary nomination units and are common in British multimedia: an alliance, an ally, an international organization, an intergovernmental organization (an igo), a security community, a system of collective security, a military organization, aggressor, a dangerous organization, criminal. The enumerated words and word combinations denote a neutral, positive and negative meaning and form a three-sided adumbration.

In the course of the investigation a spectrum of image constituents of NATO as an international military organization were distinguished in regard to the points that attract the authors of online. The article examines such depictions of NATO using numerous examples from online British media, and demonstrates how media portrayals of NATO may influence the perception of potential readers, thus defining the three-sided constructed image involving neutral, positive and negative aspects of the media image. The contraposition of a positive and negative NATO's images is scrutinized, as well as a neutral image that occupies the intermediate position. 
NATO positive media image (as presented in British mass media) is made up by means of interpreting an image of a peace-keeping international organization aiming at détente: NATO's International Security Assistance Force; prompted NATO to launch airstrikes to stop the conflict; called for NATO to do more to protect it; NATO's capabilities ... against these threats are also real and growing; Nato peacekeeping unit in Kosovo; Nato to create high-readiness force to counter Russian threat; Nato has taken a lead role in peacekeeping in the Balkans; the alliance had no intention of intervening; Nato will remain the ultimate guarantor of Britain's defence; Nato as security guarantor; Nato as the guarantor of Europe's defence; Nato, a military organisation, guarantor of the collective security of the allie; the fundamental guarantor of Europe's security; Nato forces can act as guarantors and protectors; Nato peacekeeping force; Nato is an organisation formed to defend states from aggression; Nato's effort to stabilise Afghanistan. Thus, the media image of NATO is build up by means of words with positive meaning that can be united under the following generalized semantics: a military force that is assigned to (often with international sanction) to preserve peace in a trouble area and to protect from attack. The most common words for positive NATO's image making are the following lexical units: peacekeeping and security guarantor, for example: Nato took command of the 5,000-strong international peacekeeping force in the Afghan capital Kabul today, its first ground mission outside Europe since it was created 54 years ago (The Guardian, 11 August 2003). The generalized positive media image of NATO as a military organization can be the concept of the organization interpreted as follows:

- a peacekeeper (peacemaker);

- a defender and protector;

- a guarantor of Britain's, Europe's and international security;

- a supporter to allies;

- a fighter against Russian threat.

It is noteworthy that Russia and NATO are juxtaposed in mass media as antagonists, viewed as political rivals, and conventionally lexemes Russia and NATO may be considered as contextual antonyms, as NATO is a symbol of security and stability that guarantees peace, whilst Russia is a symbol of insecurity and instability that threatens peace and security. For example, the following text segment taken from an exclusive article by NATO's outgoing Secretary General Andres Fogh Rasmussen: "In our eastern neighbourhood, Russia has shown utter disregard for international law and a brutal determination to redraw borders by force. The pattern is clear. From Moldova to Georgia, and now in Ukraine, Russia uses a mix of economic, political, propaganda and military pressures, to produce instability and manufacture hot conflicts which it can freeze at will...Russia's aggression against Ukraine has challenged our vision of a Europe whole, free and at peace." (The Independent, 16 November 2014); A BEEFED-UP Nato rapid reaction force would show Vladimir Putin that Russia would be plunged into a "decisive conflict" if it attacked a member of the alliance, according to one of the UK's top generals (The Sunday Times, 31 August 2014). NATO is characterized by means the lexeme peacemaker in media topics dealing with the Ukraine crisis, Baltic States and other postSoviet republics.

NATO's positive media image is represented by means of positive decision making; as any international organization it is vested with authority, adopts decisions reached by consensus. Media texts use the following phrases and expressions to send a message to the audience: Nato decisions require the agreement of all 19 allies; the decision means that Nato will take charge; as key Nato decisions were made; recent press coverage of NATO decisions; the decisions of the Nato foreign ministers' council in Brussels; Nato's top decision-taking body.

The positive elements within NATO's image in British mass media are influential; and the readers' perception of NATO as a peacekeeper and peacemaker has high interpenetration as it is closely connected with the connotation meaning of those that preserve and promote peace. A simplistic author-reader model of interaction shapes the purposeful meaning of a constructed image.

Nato's giving support to its allies implements a positive constituent to the alliance image and is represented by the following words and phrases used in British mass media: to offer 
(to let someone know that you are willing to do something for them); to approve (to give official agreement or permission to do something); to give an endorsement (to express support for someone especially in public); to understand (to know how someone feels as a result of experience); to agree (to have the same opinion as someone else); to give support (to provide something that someone needs). The list of such lexical units produces an impression of a powerful organization which can aid the course, policy and interests of its allies: Finland and Sweden plan to work more closely with Nato by signing a pact that allows assistance from alliance troops in the Nordic countries in emergency situations, officials said on Wednesday (The Guardian, 27 August 2014).

The next step of investigation was to deal with a negative part of NATO's image which enabled to innumerate a list of features that can be regarded as introducing the unfavorable and detrimental aspects of NATO's activities. According to the results of the content analysis of British online publications the dominant media topics that contain Nato's negative image are war conflicts in Yugoslavia, Afghanistan, Libya as well as inner divisions. The British media space concentrates on the following negative evaluation of NATO activities:

- inability to settle conflicts;

- NATO's lack of military intelligence;

- illegitimate bombardment of Yugoslavia;

- ill-prepared to confront new threats;

- the ultra-militarised NATO aggressor alliance;

- divisions between member-states;

- incredibility;

- consigned to "military irrelevance";

- Nato bureaucracy;

- ruling out interventions;

- failings of Nato's mission;

- Nato's dirty war;

- violating international law;

- tendency to fabricate facts and images;

- Nato's threat to peace.

The aforementioned ideas can be justified with the following illustrative examples: 1) Nato has wildly exceeded its United Nations mandate. It has not only taken up the role of a protagonist in the killing of civilians, but it also appears to have become an active combatant in an undeclared and illegal war against the Libyan government... And dirty, dirty work it is. Make no mistake, Nato's strategy violates international law, shows callous disregard for the innocent, and prosecutes a war approved by no international body, declared by no national parliament and sanctioned by no moral code (The Guardian, 2 May 2011); 2) There is nothing moral about the Nato intervention in Libya - it is a threat to the entire region and its people (The Guardian, 23 March 2011); 3) Nato forces also used depleted uranium weapons - linked to cancers and birth defects - while Nato bombers destroyed swathes of Serbia's economic and social infrastructure... As in Yugoslavia, so in Iraq: illegal aggression justified by spin and fabrication enables might to prevail and deals a terrible blow to the framework of international law (The Guardian, 14 August 2003);4) Nato has proved a rotten fighting force, which in Kabul is on the brink of being sidelined by exasperated Americans (The Guardian, 20 August 2008); 5) The image of the Libyan revolution in 2011 was something of a fabrication in which the decisive role of Nato air power was understated (The Independent, 25 May 2014).

A key finding from the close analysis of evaluation of NATO's image is the use of specific adjectives irrelevant, useless, slow, outdated: 1) The new force is aimed at meeting criticism that Nato is too slow and unwieldy and increasingly irrelevant (The Guardian, 5 September 2014); 2) Nato id dead-it's just that we won't admit it (The Independent, 16 June 2011); 3) On the other hand, if Nato is useless to America, it looks like being a goldmine for the Chinese, to whom the Europeans are bent on selling their military technology (The Telegraph, 22 February 2005). Creating NATO image British mass media outline the concept of a military alliance that needs restructuring, reforming both its political and military doctrine. Thus, readers receive a vivid description of an outdated, weak organization and the British media representations of NATO's missions symbolize failure, incapability to bring stability to invaded countries. Findings of the 
image studies suggest that NATO is perceived by readers as a marionette, so NATO is represented in mass media as an organization dependent on the USA, an alliance governed by Washington: $U S$ presses Nato member to increase defence spending. The semantics of the verb to press means to exert force, to try to influence, as by insistent arguments, to urge or force to action, to impel. The structured NATO's image is that of an organization with no political power.

NATO's image is also conceptualized in British newspapers as an alliance with internal conflicts that are metaphorically represented as a marriage: The Hungarian, Czech and Polish governments, blushing new brides at Nato's altar, are now pale-faced and nervous, wondering whether they will survive the war. They had married Nato because of the generous dowries that might follow. The rude honeymoon has shocked them (The Guardian, 26 May 1999). The inner conflicts are depicted in a great many articles and produce the impression of a non-stop fighting, clash, for example: Washington and several of its European allies were divided last night... (The Guardian, 1 December 2008).

The image of North Atlantic treaty organization is outlined in British mass media as a type of military alliance that is unknown to citizens of member countries: $60 \%$ of those polled in Nato countries say they know little or nothing about the alliance (The Guardian, 28 August 2014).

The neutral mass media image of NATO as military and political organization is mostly represented by means of the following lexical units: an organization, a military alliance, NATO war-games.

The results of the investigation carried out suggest that the negative and positive verbal ways (both explicit and implicit) of evaluating the complex NATO's image in the British press stereotype two key images: a peacemaker and a hawk, that are arranged into the conceptual unity "Natoland". This is typical of the British media space though the concept of media space is problematic today [14, p. 260].

Findings of the studies demonstrate that the NATO's media image in the British online press possesses a finite spectrum of positive and negative evaluation; it is depicted not only on the lexical level but on the intertextual level.

\section{REFERENCES}

1. Hawk B.G., ed. Africa's Media Image. New York, Praeger, 1992. 268 p.

2. Badsey S., Latawski P. Britain, NATO and the Lessons of the Balkan Conflicts, 1991-1999. London, Frank Cass, 2004. 288 p.

3. Breuer I., Napthine M., O'Shea R. Persuasive Language in Media Texts. Insight Publications Pty Ltd., 2008. 147 p.

4. Dourish P. Where the Action is: The Foundations of Embodied Interaction. MIT Press, $2004.245 \mathrm{p}$.

5. Edwards M. Key Ideas in Media. Nelson Thornes Ltd., 2003. 192 p.

6. Ungerer F., ed. English Media Texts, Past and Present: Language and Textual Structure. John Benjamins B.V., 2000. 286 p.

7. Fulton H., Huisman R., Murphet J., Dunn A. Narrative and Media. Cambridge University Press, 2006. $342 \mathrm{p}$.

8. Gillespie M., Toynbee J. Analysing Media Texts. Open University Press, 2006, vol. 4. 205 p.

9. King C.R., Echo-Hawk W.R., Rosier P. Media Images and Representations. Chelsea House Publishers, 2009. $117 \mathrm{p}$.

10. Kornetzki A. Contrastive Analysis of News Text Types in Russian, British and American Business Online and Print Media. Berlin, Frank and Timmer $\mathrm{GmbH}, 2011.357 \mathrm{p}$.

11. McDougall J. Media Studies: The Basics. London, Routledge, 2012.211 p.

12. Graddol D., Boyd-Barrett O., eds. Media Texts, Authors and Readers: A Reader (Language and Literacy in Social Context). Clevedon, Multiligual Matters, The Open University, 1994. $282 \mathrm{p}$.

13. Moor R.R. NATO's New Mission: Projecting Stability in a Post-Cold War World. New York, Praeger, 2007. $224 \mathrm{p}$.

14. Asselin O., Lamoureux J., Ross C., eds. Precarious Visualities: New Perspectives on Identification in Contemporary Art and Visual Culture. Montreal, McGills-Queen's University Press, 2008. $438 \mathrm{p}$.

15. Min E., ed. Reading the Homeless: The Media's Image of Homeless Culture. Greenwood Publishing Gr., 1999. 222 p.

16. Yahya R. Kamalipour, ed. The U.S. Media and the Middle East: Image and Perception. New York, Praeger, 1997.264 p.

17. Valuyskaya O.R. Interpretativnost kak potentsialnoe svoystvo teksta [Text Interpretativity as a Potential Feature]. Vestnik Volgogradskogo gosudarstvennogo universiteta. Seriya 2, Yazykoznanie [Science Journal of 
Volgograd State University. Linguistics], 2012, no. 2, pp. 210-215.

18. Valuyskaya O.R. Sovremennye obrazy mediateksta (na materiale angloyazychnykh internet-istochnikov) [Modern Media Text Images (the Case Study of British and American Internet Resources)]. Volgograd, VolSU, 2011. 72 p.

\section{SOURCES}

The Independent. Available at: http:// independent.co.uk.

The Guardian. Available at: http:// theguardian.com/uk.

The Telegraph. Available at: http://telegraph.co.uk.

\section{ЛИНГВИСТИЧЕСКИЕ ОСОБЕННОСТИ МЕДИЙНОГО ОБРАЗА НАТО (НА МАТЕРИАЛЕ БРИТАНСКИХ ИНТЕРНЕТ-ПУБЛИКАЦИЙ)}

\section{Валуйская Ольга Руслановна}

Кандидат филологических наук,

доцент кафедры английской филологии,

Волгоградский государственный университет

ovalvolsu@mail.ru, english_philology@volsu.ru

просп. Университетский, 100, 400062 г. Волгоград, Российская Федерация

Аннотация. В статье на материале ведущих газет Великобритании исследуется лингвистическая специфика создаваемого в медийном Интернет-пространстве образа НАТО. Автор рассматривает новостные и аналитические статьи, в которых дана оценка деятельности Северо-Атлантического Альянса. Изучение проводилось с опорой на принципы медиалингвистического подхода, позволившего представить медиаобраз как трехмерное структурное образование, включающее положительную, отрицательную и нейтральную составляющие, которые репрезентируются в медийном тексте. Медиаобраз НАТО предлагается рассматривать как образ геополитического актора, который создает свое военное и политическое пространство. В статье анализируются медиатопики, в рамках которых создаются положительные и отрицательные медийные образы НАТО как действующей военной организации. Приведен список лексических единиц, которые передают положительную или отрицательную оценку деятельности Альянса. С использованием условной модели интеракции журналиста и читателя, позволяющей представить образ объекта, формируемый получателем информации, показаны возможности интерпретации читателем медийного образа НАТО как концептуального единства двух ключевых образов - образа миротворца и поджигателя войны, что наглядно демонстрируется на лексическом и межтекстовом уровнях.

Ключевые слова: медийный образ, медийное пространство, медиатекст, массмедиа, оценка, негативная оценка, лексический уровень, межтекстовый уровень. 